\title{
Design of a HACCP Plan for Vacuum-Packed Beef Cuts
}

\author{
Almeraya-Soberanes, Lucero I. ${ }^{1}$; Guajardo-Hernández, Lenin Gerardo ${ }^{2 *}$; Almeraya-Quintero, Silvia Xochilt ${ }^{2}$; \\ González-Rodríguez, Mario Salvador ${ }^{2}$; Almeraya-Soberanes, Sonia ${ }^{2}$
}

${ }^{1}$ Investigadora Independiente. ${ }^{2}$ Colegio de Posgraduados. Carretera México-Texcoco Km. 36.5, Montecillo, Texcoco, Estado de México. C.P. 56230. Tel 0159595202 00. Ext. 1876. Posgrado en Socio economía, Estadística e Informática-Desarrollo Rural.

*Corresponding author: glenin acolpos. $\mathrm{mx}$

\begin{abstract}
Objective: To elaborate a Hazard Analysis and Critical Control Points (HACCP) plan for the process of vacuum-packed beef cuts, in a Federal Inspection Type (FIT) meat processor located in eastern Estado de México, with the aim of improving its conditions of hygiene and innocuousness.
\end{abstract}

Design/Methodology/Approximation: The activities performed in the business were revised applying the HACCP methodology and the dangers identified were analyzed, to determine whether the danger found was significant for the innocuousness of the food, finally concluding if it represented, or not, a critical control point (CCP).

Results: A CCP was identified in the phase of metal detection, the dangers identified were the passing of metal shards from the transport rails, pieces of knives or saws, and pieces of needles from prior steps in the process.

Study limitations/implications: Documentation about case studies of beef cuts, as well as about management of their CCP is limited

Findings/Conclusions: The CCP1 Metal Detection is a control measure that the business performs; however, under analysis, there was evidence of an opportunity to improve the current operation, which is why the adaptation of registry formats that could allow monitoring and controlling the CCP was proposed.

Keywords: CCP, FIT, meat cuts, innocuousness, packaging

\section{INTRODUCTION}

The Hazard Analysis and Critical Control Points (HACCP) system, which has scientific foundations and systematic nature, allows identifying specific dangers and control measures in order to guarantee innocuousness of foods. It is an instrument to evaluate the dangers and establish control systems that are focused on prevention instead of being based primarily on testing the final product (CODEX ALIMENTARIUS, 2005). The HACCP system can be applied all along the entire food chain, from the primary producer to the final consumer, and its application must be based on scientific trials of dangers for human health. In addition to improving the safety of foods, applying the HACCP system can offer other significant advantages, also facilitating the inspection by the regulatory authorities, and promoting international trade by increasing the confidence in the innocuousness of the foods (CODEX ALIMENTARIUS, 2005). 
Currently, the importance of food safety is reflected not only in the need to avoid health problems, but also in the repercussions from trading contaminated foods. All of these circumstances have led to methodologies being created, designed or adapted, or systems that allow guaranteeing or ensuring the innocuousness and quality of foods (Nápan \& Pérez, 2017).

Meat is a food rich in nutrients that provides the ideal conditions for microbes to grow and this defines its perishable nature. Some organisms simply ruin it, while others make it a threat for health (Saucier, 2016) Deterioration is a complex process where a combination of chemical and biological mechanisms occurs that makes the product unacceptable (García et al., 2015). The foods most frequently involved in epidemics and cases of foodborne diseases (FD) are those of animal origin. In $48 \%$ of the epidemics that took place between 1973 and 1987 in the USA, where the causal factor was identified, the products involved were beef, eggs, pork meat, poultry meat, fish, crustaceans, mollusks, or dairy products (OMS, 2016).

The Hazard Analysis and Critical Control Points (HACCP), which strongly depends on prerequisite programs that include Best Hygiene Practices (BHP) and Standard Sanitation Operating Procedures (SSOP) provides better hygiene conditions of the process that are necessary for meat production and safe meat products in the meat chain (Tomasevic et al., 2016)

A FIT (Federal Inspection Type) establishment is an animal slaughter facility for supply, refrigerating and industrialization of meat products and byproducts that is object of permanent sanitary inspections to ensure that they comply with the regulations that the Ministry of Agriculture and Rural Development (Secretaría de Agricultura y Desarrollo Rural, SADER) marks for Mexico considering food safety (SENASICA, 2015). Currently the clients are increasingly more demanding in terms of the conditions of the products they enjoy, which is why they seek those that satisfy their expectations and offer confidence and safety. Beef consumption in Mexico is important. Data from 2014 indicate that the consumption of this type of food in Mexico was 1.85 million tons. However, only $48 \%$ of it came from Federal Inspection Type (FIT) meat processors, while the other $52 \%$ came from municipal meat processors (Ventura et al., 2017). This study aims to design a proposal for a HACCP plan in processing of vacuum-packed secondary beef cuts, for a meat cut packer that recently obtained its FIT certification, located in eastern Estado de México, to ensure innocuousness.

\section{MATERIALS AND METHODS}

The study is centered on a business that is a Federal Inspection Type (FIT) meat processor, located east of Estado de México and west of Mexico City, which has a chamber for slaughter, deboning, carving, packing, packaging and storing meat cuts. The research had a field phase where the HACCP methodology was applied in terms of the revision of activities carried out in the business, with the aim of identifying all the physical, chemical and biological potential dangers that it is essential to anticipate in the production process, and another analysis phase of the dangers identified during the first, with the purpose of defining whether the danger found is significant for food innocuousness, and thus, through the use of a decision tree to conclude if the stage evaluated was a critical control point (CCP) or not. The agroindustry selected is a medium-sized business that has 36 workers distributed in the different areas; it is focused on slaughter and obtaining meat byproducts. The process that was used for the development of the HACCP plan is obtaining vacuum-packed secondary beef cuts. With the visits carried out to the packaging plant, through observation and collection of documental information, the preliminary tasks and the HACCP principles were developed.

\section{Sequence for the implementation of the HACCP system}

- Training the HACCP team.

- Describing the product

- Defining the use and destination of the product.

- Elaborating the flow diagram of the process.

- In situ confirmation of the flow diagram.

- Analyzing dangers (principle 1).

- Determining critical control points (CCP) (principle 2).

- Establishing the critical limits (principle 3).

- Designing a security system (principle 4).

- Designing corrective measures (principle 5).

- Designing verification and validation procedures (principle 6)

- Designing a registry and documentation system (principle 7).

\section{RESULTS AND DISCUSSION}

\section{Training of the HACCP Team}

In the first meeting the study's objectives were made 
public; in the second meeting an organigram was proposed to guarantee the reliability of the system, which was made by the advisory team and operating manager, validated by the general director, and the other members of the HACCP team were selected, the positions and responsibilities of each member of the team are shown next.

- Quality chief (leader) with the responsibility of coordinating the team to achieve the objectives established.

- Operating manager (facilitator) with the responsibility of providing tools, data and information of importance to the product.

- Systems manager (secretary) with the responsibility of performing the registry of meetings and agreements, in addition to filing, consulting and receiving documentation.

- Advisory team with the responsibility of guiding and maintaining communication with all the areas during product development.

\section{Product Description}

The product is obtained from the secondary beef cuts, vacuum packed, refrigerated or frozen, according to the client's request. They come from deboning of front and back quarters of the cattle carcass, destined for human food and wrapped in polyethylene sheets and vacuum bags, packed in cardboard boxes or plastic baskets, and sent out at 0 to $4{ }^{\circ} \mathrm{C}$ when refrigerated or at -18 ${ }^{\circ} \mathrm{C}$ when frozen. The product should be free of clots, filth and should have a bright red color, with white or slightly yellow fat, and characteristic odor (NOM 251SSA1; 2009). It was found that the business carries out these activities completely and maintains the criteria of the cold chain, as well as the organoleptic characteristics established by the norm for production of this product.

\section{Determination of the Use and Destination of the Product}

The product is destined to self-service stores for its sale, distribution and consumption; it is recommended to follow the next instructions for safe management of the meat cuts obtained:

- Keep refrigerated or frozen at a temperature of -18 to $4^{\circ} \mathrm{C}$.

- Thaw in refrigerator at a maximum temperature of $4{ }^{\circ} \mathrm{C}$, to keep the cold chain of the product and preserve its shelf life.
- Keep the raw meat separate from other types of foods in the store.

- Cook completely, making sure to have reached total cooking.

- Once the package is open, consume the whole product.

- It is recommended to cook for 10 to 12 min or until the internal temperature of the meat reaches $68^{\circ} \mathrm{C}$ minimum.

- Do not consume the product raw.

\section{Process Flow Diagram and in situ Verification}

Figures 1, 2 show the phases of the process, from the moment of the reception of the half carcasses until the vacuum-packed meat cuts are obtained, which was verified and corrected according to the changes found in the in situ verification. A path diagram was also developed that helped to identify the phases of the process, thus fulfilling the last Pre-HACCP activity.

\section{HACCP Principles}

Analysis of dangers (Principle 1)

Derived from the analysis of dangers, probability and severity were identified for each of them, and their significance was evaluated with the support from the severity framework of the HACCP methodology. The most important biological dangers of the production process of vacuum-packed meat cuts are: E. coli O157:H7, Salmonella spp. and Listeria monocytogenes, which can be introduced from the slaughter until the moment of eviscerating or from the incorrect manipulation of the carcass on the product by the staff. Salmonella spp. is a primarily intestinal parasite bacterium of animals including humans, liberated to the environment from feces, where certain survival ability is shown in the materials that it contacts; under favorable conditions, it multiplies (Caballero, 2008). This can be prevented with a staff Hygiene Program, or in later steps of the process, such as vacuum packing to reduce microbial growth. Maldonado (2013) recommends improving animal slaughter, as well as the sanitary conditions in meat processors, since contamination of the meat on the carcass is the direct result of the transfer of pathogens present in cattle and its later meat contamination. This is what various studies suggest, arguing that beef consumption is associated with infections produced by Salmonella spp. and E. coli 0157:H7.

Within the beef cutting process and according to the bibliography, clenbuterol is identified as the most 
important chemical danger; it is an anabolic agent that is used illegally in livestock production to increase the weight in bovines and other species. High doses are required for clenbuterol to express its anabolizing function, which is why residues in meat represent a danger for consumers, who can present severe intoxication (COFEPRIS, 2018). Therefore, it is recommended to implement a reliable supplier program (FIT Meat Processor) to prevent purchasing meat contaminated with clenbuterol, and to request a certification of Reliable Producer from SAGARPA along with the implementation of a traceability program.

Jiménez (2011) found between the years 2002 to 2008, more than two thousand cases of intoxication from clenbuterol in Jalisco, Distrito Federal, Guanajuato and Michoacán, which are the states with most cases. The use of clenbuterol has become a problem not only of public health but also of economic and ethical type, since it represents profits for those who distribute it and use it regardless of the consequences; therefore, coordinated actions, timely information, and strict observance of the law could contribute to the compliance of the demand for healthy and innocuous meat products. Based on the Federal Law of Animal Safety, the foundations are provided to SAGARPA for this ministry to carry out the activities that lead to legal action against those who use clenbuterol illegally.
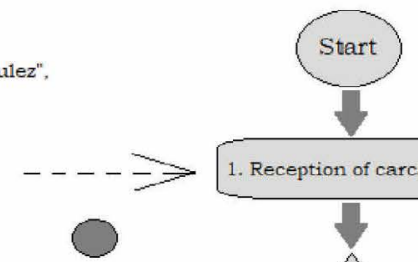

1. Reception of carcasses

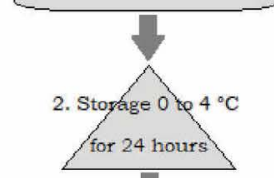

Shrink bag for high vacuum packaging

3. Rail transfer

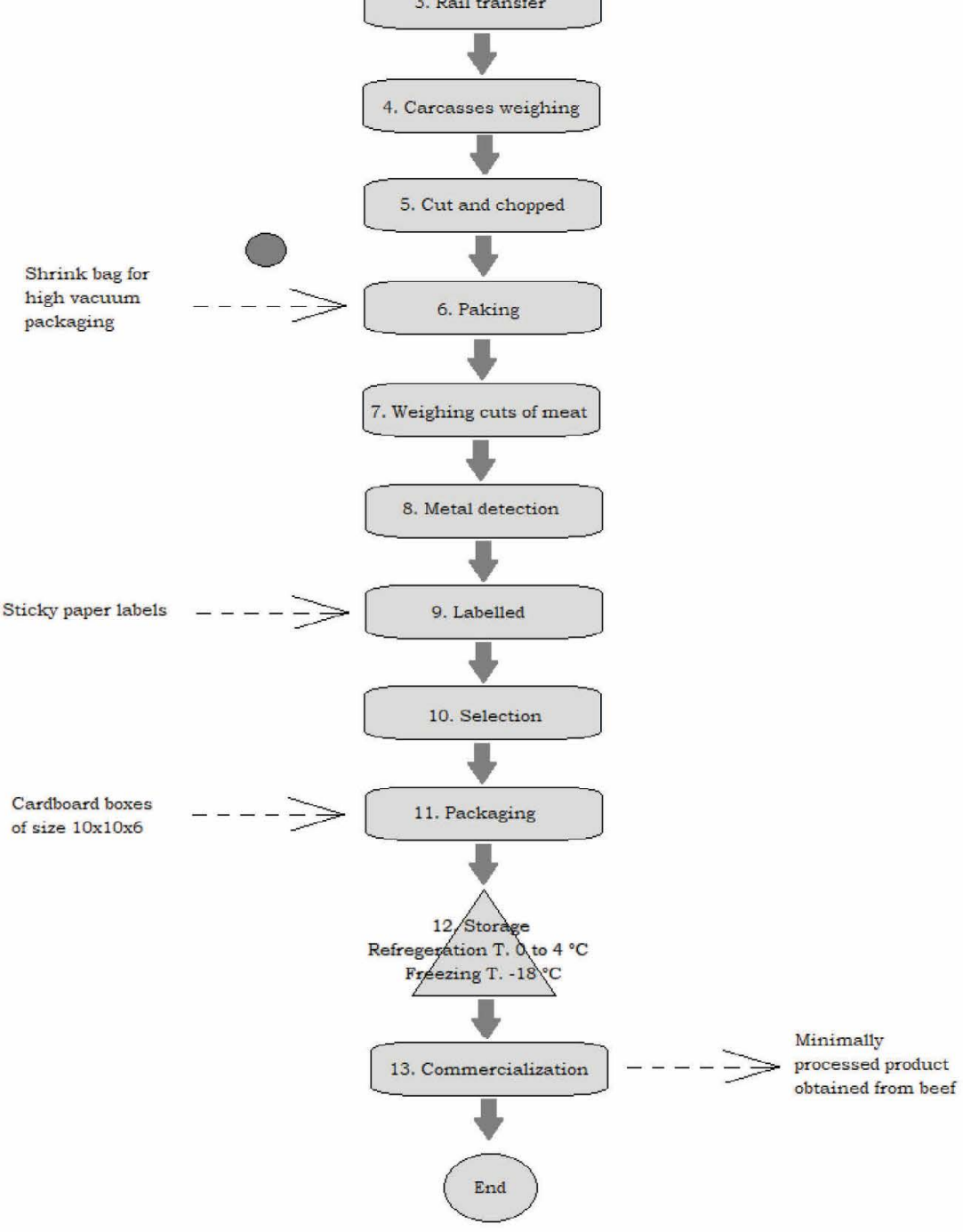

Figure 1. Flow diagram of the meat cuts processing. Source: Prepared by authors

Evidences of meat contaminated with this chemical were not found in this study; the documents that certified the supplier and endorsed the livestock as clenbuterol-free animals were reviewed. The most important physical dangers of the production process were wires that can come from the slaughter process and presence of metal pieces from utensils used in the cutting and deboning phase (knives, saws, metallic mesh gloves), although this can be prevented with the revision of equipment and work tools and with a metal detector. The chemical and biological dangers mentioned before were not significant; however, the physical dangers mentioned were 


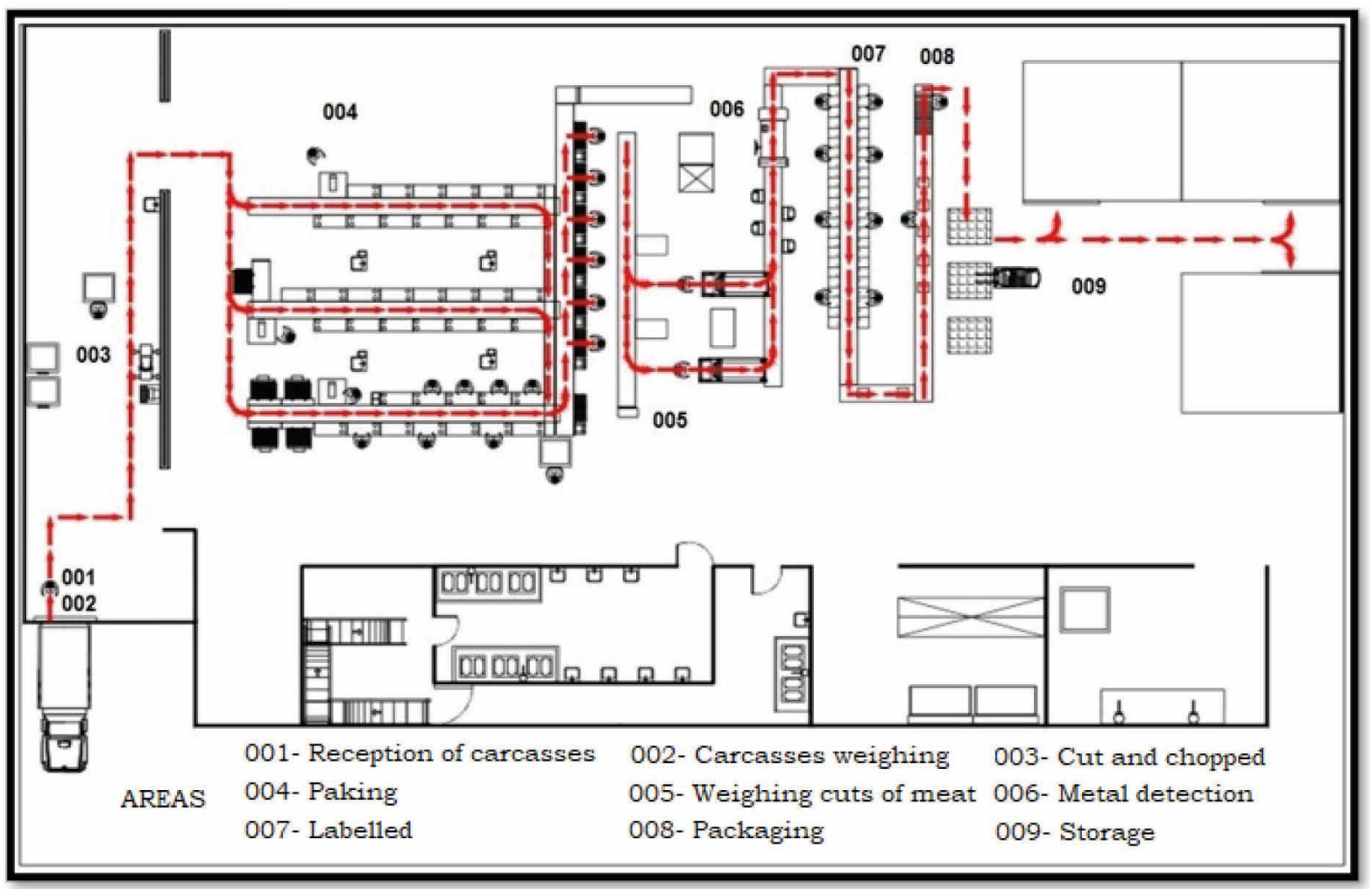

Figure 2. Path diagram of the vacuum-packed meat cuts process. Source: Prepared by authors.

significant and it is necessary to take adequate control measures to manage the risk that was identified in the phase of metal detection.

\section{Defining Critical Control Points (Principle 2)}

In the metal detection phase dangers were identified that come from steps prior to the vacuum packaging of beef, which could be metal shards from rails, pieces of knives or saws from the cutting area, and pieces of needles from applying injections on the live animal. With the decision tree diagram, it was determined that the phase of metal detection is a critical control point (CCP). To control the physical danger, such as metal and wire fragments in the meat, a metal detector should be used as indicated by the National Institute of Normalization (2012).

The United States Department of Agriculture (USDA, 1999), in its general HACCP publication for raw ground products of beef and poultry, established the metal detector as a CCP since it is a control measure for contamination with metal shards, regardless of whether these are introduced by means of the packaging process or in some other point prior to this; it specifies that no metal particle can be bigger than $0.079 \mathrm{~cm}(0.0313$ inches) in size.

\section{Establishing Critical Limits (Principle 3)}

The critical control point detected was called the critical limit, according to the characteristics of the equipment used in this phase, which is the case of the sensitivity of the metal detector, with a range of no more than $2.5 \mathrm{~mm}$ for iron and non-iron metals and for stainless steel no more than $0.5 \mathrm{~mm}$, a maximum band speed of $4 \mathrm{~m} \mathrm{~s}^{-1}$. According to the United States Department of Agriculture (USDA, 1999) in its general HACCP publication for raw meat and poultry products, the critical limit in metal detectors is established where no metal particle could be larger than $0.079 \mathrm{~cm}$ (0.0313 inch) in size.

\section{Establishing a Security System (Principle 4)}

In order to guarantee the fulfillment of the critical limits in the size of metallic residues established, a security method is proposed, by assigning one person in the plant to carry out this activity, who will be in charge of controlling the calibration of the metal detectors, which must pass "pattern samples" with different sizes of metallic residues under the detection arch every hour, respecting the sensitivity parameters of the metal detector and the band speed. There are very modern metal detectors that have an auto-control system, and therefore, they are free of maintenance while others do require verification 
after long periods of operation to confirm that they still function correctly (Monreal, 2011).

\section{Establishing Corrective Actions (Principle 5)}

Two corrective actions were proposed that are mentioned next: the immediate, which is when the pattern samples could not be identified by the metal detector, and the process must be stopped at that moment to pass the total product of the lot in the most recent hour through the metal detector; and the preventive, which is to verify that the metal detector works with the corresponding parameters, monitoring and calibrating each hour with a pattern sample and every $4 \mathrm{~h}$, with band speed at $4 \mathrm{~m}$ $s^{-1}$.

\section{Establishing Verification Procedures (Principle 6)}

Verification of the frequency established proposed by the team should be carried out by trained staff, through monitoring in one-hour lapses, confirming that the operation is being performed correctly and making the corresponding record.

\section{Establishing Documentation for All the Procedures and Records (Principle 7)}

To carry out the evidence of verifications, preventive and corrective actions, the elaboration of registry and vigilance formats for the CCP was proposed. For example in metal detection, the times, calibration, maintenance and person in charge of doing the operation should be recorded.

When identifying the phase of metal detection as Critical Control Point, the critical limits were established (minimum and maximum size of iron, non-iron and stainless steel residues) according to the characteristics of the equipment used by the business. The most important functioning parameter of the metal detector is the sensitivity for the detection of particles: with a range not larger than $2.5 \mathrm{~mm}$ for iron and non-iron metals, and not larger than $0.5 \mathrm{~mm}$ for stainless steel; the other parameter was the maximum band speed of 4 $\mathrm{m} \mathrm{s}^{-1}$. Once the critical limits were established, vigilance procedures were proposed assigned to a person in the plant to carry out such an activity, through good control in the calibration of metal detectors, making pattern samples pass under the detection arch, with frequency of $1 \mathrm{~h}$, respecting the sensitivity parameters of the metal detector and band speed. In case of there being a deviation in the critical control point identified, immediate and preventive measures are established as well as monitoring and supervision to confirm that the operation is performed correctly, and making the corresponding registry in the formats proposed.

\section{CONCLUSIONS}

The CCP1 metal detection is a measure that is carried out in the business; however, when defining its critical limits and monitoring activities, an opportunity to improve the current operation was evidenced. This confirms the importance of the HACCP methodology as an essential system for the detection of the CCP which allows guaranteeing businesses the innocuousness of their products.

\section{ACKNOWLEDGEMENTS}

To the meat cuts packaging plant for the support provided for the development of the HACCP plan, as well as for providing access to the plant and information

\section{REFERENCES}

Caballero, T. A. E. 2008. Temas de Higiene de los Alimentos. La Habana, Cuba. Editorial Ciencias Médicas.

CODEX ALIMENTARIUS, (2005). Higiene de los alimentos Textos básicos. Roma, Programa Conjunto FAO/OMS sobre Normas Alimentarias, Recuperado de: http://www.fao.org/docrep/009/ y5307s/y5307s00.htm\#Contents

Comisión Federal para la Protección contra Riesgos Sanitarios (COFEPRIS). 2018. Materiales para la difusión sanitaria de Clembuterol. Gobierno de México. Disponible en: https:// www.gob.mx/cofepris/documentos/materiales-para-ladifusion-sanitaria-de-clenbuterol-52549?state=published

Departamento de Agricultura de los Estados Unidos. (USDA). (1999) Modelo HACCP general para productos crudos molidos de carne y aves. Food Safety and Inspection Service. Disponible en: https://www.pdffiller.com/jsfiller-desk4/?projectld=19926 8332\&expld =3570\&expBranch =3\#14255af955cb4dac8688b1 $8107 a e 5200$

Garcia A., Brugnini. G., Rodriguez S., Mir A., Carriquiry J., Rufo C. \& Briano B., (2015). Vida útil de carne fresca de res envasada al vacio a $0^{\circ} \mathrm{C} \mathrm{y}+4^{\circ} \mathrm{C}$. Producción agropecuaria y desarrollo sostenible, vol (4). 27-45. Disponible en: http://www.diyps catolica.edu.sv/wpcontent/uploads/2016/06/2VidaCarneFresc aPAyDSVol4.pdf

Instituto Nacional de Normalización. (2012). Directrices para carnes y productos cárnicos. Disponible en: http://www chilealimentos.com/medios/Servicios/NormasNacionales/ INN/ConsultaPublica/INN_GUIA_01_2012_043.pdf.9

Jiménez S. L., Garza R. J., Suamano L. H., Fragoso S. H. (2011). Vigilancia en el uso ilícito del clembuterol y su coordinación intersectorial en dos entidades de México. Veterinaria México. Vol. 42 (1). Pág. 11-25. Disponible en: http://www.redalyc.org/ articulo.oa? $\mathrm{id}=42318919002$

Maldonado C., Tello G., Tejada F. Ramírez B. y Flores M. 2013. Estudio preliminar para investigar salmonella sp. y e. coli 0157:H7 en carne molida de res, de venta en supermercados de la Ciudad 
de Puebla, México. CienciasUAT, vol. 8. Núm.1. Universidad Autónoma de Tamaulipas. Cuidad Victoria, México.

Monreal R. L. (2011). Detector de Metales y HACCP. Industria Alimentaria. Disponible en: https://www. industriaalimenticia.com/articles/83100-detector-de-metales-y-haccp.

Norma Oficial Mexicana NOM-213-SSA1-2002. 2002. Productos y servicios. Productos Cárnicos procesados. Especificaciones sanitarias. Métodos de prueba.

Nápan L. \& Pérez S., (2017) Elaboración de un plan HACCP para la línea de cortes de carne de cerdo refrigerados en la Empresa Pecuaria Gutiérrez S.A.C. (tesis de titulación). Universidad Nacional Agraria la Molina, Lima, Perú.

Organización Mundial de la Salud, (2016). Enfermedades transmitidas por alimentos (ETA). Washington D.C., Estados Unidos de América. Pan American Health Organization. Disponible en: https://www.paho.org/ hq/index.php?option=com_content\&view $=$ articlefid=10836\%3A2015-enfermedades-transmitidas-poralimentos-eta\&catid $=7678 \% 3$ Ahaccp\&ltemid $=41432$ lang $=$ es

Saucier L. (2016). Microbial spoilage, quality and safety within the context of meat sustainability. Elsevier, vol (120). 78-84. Disponible en: https://www.sciencedirect.com/science/article/pii/S0309174016301206

Servicio Nacional de Sanidad, Inocuidad y Calidad Agroalimentaria, (2016). Establecimientos Tipo Inspección Federal (TIF). Disponible en: https://www.gob.mx/senasica/acciones-y-programas/establecimientostipo-inspeccion-federal-tif

Tomasevic I., Kuzmanović J., Anđelković A., Saračević M., Stojanović M. \& Djekic I., (2016). The effects of mandatory HACCP implementation on microbiological indicators of process hygiene in meat processing and retail establishments in Serbia. Elsevier vol. (114). 54-57. Disponible en: https://www.sciencedirect. com/science/article/pii/S0309174015301467

Ventura G., Parra C., Toledo G., Barcelos 1. \& Girón I., (2017). Determinación de Salmonella spp por qPCR en carne de res procedentes de rastros tipo inspección federal (TIF) y no TIF. Revista Bio Ciencias 4(5). p-14. Disponible en: http://revistabiociencias.uan.mx/index.php/BIOCIENCIAS/article/viewFile/347/308 